\title{
Effect of aging on myo-inositol and phosphoinositide metabolism in the cochlear and vestibular sensory epithelia of the rat
}

\author{
Kaoru Ogawa, John McLaren, Jochen Schacht * \\ Kresge Hearing Research Institute, University of Michigan, 1301 East Ann Street, Ann Arbor, MI 48109-0506, US.4
}

(Received 15 June 1993; Revision received 6 October 1993; Accepted 9 October 1993)

\begin{abstract}
Ncurotransmission and transmembrane signaling are among the cellular mechanisms affected in the aging nervous system. In the inner ear, the phosphoinositide second messenger cascade is of particular interest as a target of the aging process. In both the cochlear (CSE) and vestibular sensory epithelia (VSE), the hydrolysis of phosphatidylinositol 4,5-bisphosphate (PtdIns $\mathrm{P}_{2}$ ) to the second messenger inositol 1,4,5-trisphosphate ( $\left(\mathrm{ns}_{3}\right)$ is coupled to muscarinic cholinergic and $\mathrm{P}_{2 \mathrm{y}}$ purinergic receptors and may be linked to calcium homeostasis. The present study compared the turnover of phosphoinositides (PtdInsPs), receptor-mediated release of inositol phosphates (InsPs), and concentrations of endogenous myo-inositol in the CSE and VSE of young (3 months) and aged (24 months) Fischer-344 rats. In the aged rat, there was a significant increase in $\left[{ }^{3} \mathrm{H}\right]$ inositol incorporation (per mass of protein) into PtdInsPs plus InsPs in both sensory epithelia while the protein content remained unchanged. In contrast, no age-dependent differences were found when pre-labeled $\left[{ }^{3} \mathrm{H}\right] \mathrm{PtdI} n \mathrm{Ps}$ were 'chased' with non-radiolabeled myo-inositol indicating that the turnover of these lipids was unaffected. The cholinergic receptor agonist carbamylcholine and the $\mathrm{P}_{2}$ purinergic receptor agonist adenosine $5^{\prime}$-O $-\left(3\right.$-thiotriphosphate) stimulated the release of $\left[{ }^{3} \mathrm{H}\right] \mathrm{InsPs}$ two- to six-fold in both organs. This agonist-stimulated release of $\left[{ }^{3} \mathrm{H}\right] \mathrm{InsPs}$ (per mass of protein) was significantly higher in aged animals. However, when the same stimulation was expressed as per cent of control values, there was no age-dependent difference. Finally, the concentration of endogenous myo-inositol decreased by $44 \%$ in the aged CSE and by $24 \%$ in the aged VSE. In contrast, levels of added myo- $\left[{ }^{3} \mathrm{H}\right]$ inositol were higher in aged tissues. These results suggest that the increased labeling of PtdInsPs and InsPs in the aged CSE and VSE is a consequence of the increased specific radioactivity of the myo- $\left[{ }^{3} \mathrm{H}\right]$ inositol precursor pool. The activity of the phosphoinositide second messenger pathway thus appears unchanged. However, a decreased myo-inositol content may contribute to age-dependent pathology in these tissues. myo-Inositol is an organic osmolyte and volume regulator. Changes in osmotic pressure or turgor of hair cells could alter micromechanical coupling on the basilar membranc and vestibular epithelium causing pathophysiological changes in sensory transduction.
\end{abstract}

Key words: Aging; Inositol phosphates; Phosphoinositides; Myo-inositol; Second messenger; Cochlea; Vestibule; Rat, Fischer-344

\section{Introduction}

Age-related decreases in hearing sensitivity and increased incidence of equilibrium dysfunction are well documented in the human (Schuknecht, 1974; Oosterveld, 1983) and in experimental animals (Willott, 1991, for review). In both the cochlea and vestibule, one prominent morphological change during aging is the gradual loss of hair cells. In the cochlea, hair cells are characteristically lost at one or both extremes of the organ of Corti, with a higher susceptibility of the outer

\footnotetext{
* Corresponding author. Fax: (313) 764-0014.
}

hair cells in most species. However, physiological determinations of sensory deficits frequently do not correspond to hair cell pathology, suggesting that more subtle changes in cell function may underlie some of the age-related dysfunctions.

Neurotransmitter mechanisms and intracellular homeostasis and regulation are among the metabolic processes affected in the aging nervous system (Gibson and Peterson, 1987; Barritt, 1987; for review). Signal transduction may be a specific target and in particular, the inositol 1,4,5-trisphosphate ( $\left.\operatorname{Ins}_{3}\right)$ second messenger system. $\mathrm{InsP}_{3}$ is produced by the receptor-mediated hydrolysis of phosphatidylinositol 4,5-bisphosphate (PtdInsP $\mathrm{P}_{2}$ ) in response to neurotransmitters and hor- 
mones (Henzi and MacDermott, 1992; Berridge, 1993; Irvine, 1993; for review). It serves to elevate intracellular calcium which, in turn, plays a central rolc in cell physiology by controlling a diversity of biochemical events ranging from metabolic regulation to cell death. Aging affects the $\operatorname{InsP}_{3}$ second messenger system in various organs, including brain (Crews et al., 1986; Nalepa et al., 1989; Burnett et al., 1990a,b; Joseph et al., 1990; Mundy et al., 1991; Ohnuki and Nomura, 1991; Kurian et al., 1992; Undie and Friedman, 1992), pineal gland (Tandon et al., 1991; Laitinen et al., 1992), pituitary gland (Bonnetti et al., 1987), liver (Borst and Scarpace, 1990), heart (Miyamoto and Ohshika, 1989; Moscona-Amir et al., 1989), parotid gland (Ishikawa et al., 1988), tracheal smooth muscle (WillisKarp, 1991), granulocyte (Fulop et al., 1989) and platelets (Bastyr et al., 1990).

In addition to being a precursor of the phosphoinositides, myo-inositol is an important factor in cell growth and maintenance. Nutritional deficits or decreases in its tissue content have been implicated in pathological processes leading to inadequate growth and even cell death (see review by Wells, 1989). At the cellular level, myo-inositol acts as a major osmoregulator in the kidney (Garcia-Perez and Burg, 1990) and in other tissues including brain (Paredes et al., 1992). In the aged human brain, myo-inositol is decreased to half the level in young brain (Stokes et al., 1983).

In the cochlear (CSE) and vestibular sensory epithelia (VSE) of guinea pig and rat the $\operatorname{InsP}_{3}$ second messenger system is coupled to muscarinic and purinergic $P_{2 y}$ receptors (Guiramand et al., 1990; Niedzielski and Schacht, 1991, 1992; Niedzielski et al., 1992; Ogawa and Schacht, 1993a) and may thus be linked to neurotransmission and modulation. Nothing is known about the possible role of myo-inositol in cochlear or vestibular osmoregulation. In this study, we compared the activity of the phosphoinositide second messenger system and the concentrations of myo-inositol in the CSE and VSE of 3-month-old and 24month-old Fischer-344 rats. Around 24 months of age, rats show electrophysiological changes in the auditory periphery such as elevation of thresholds to clicks and tone pips (Cooper et al., 1990; Simpson et al., 1985). Some of these results have been presented in a preliminary report (Ogawa and Schacht, 1993b).

\section{Materials and methods}

\subsection{Materials}

Fischer-344 rats (3 months old, male; Charles River Lab., Kingston, NY; and 24 months old, male, National Institute of Aging Colonies, obtained through HarlanSprague-Dawley, Indianapolis, IN) were used in this study. myo- $\left[{ }^{3} \mathrm{H}\right]$ Inositol (specific activity $82 \mathrm{Ci} / \mathrm{mmol}$ ! was obtained from Amersham (Arlington Heights, IL). I lanks' balanced salt solution (HBSS) from Giboo BRI. Life Technologies (Gaithersburg, MD), and high performance thin layer chromatography (HPTLC) plates (Silica gel 60) from Merck (Cherry Hill, NJ). Other reagents were purchased from Sigma Chemical Co. (St. Louis, MO).

\subsection{Tissue preparation}

Rats were decapitated, the otic capsules quickly removed from the temporal bone and placed in incubation buffer (see below) at room temperature. The otic capsule was opened and the sensory epithelia were removed by microdissection and kept in the incubation buffer. The tissue defined here as 'cochlear sensory epithelium' (CSE) consisted of inner and outer hair cells, supporting cells, basilar membrane and the lateral part of the spiral limbus; the 'vestibular sensory epithelium' (VSE) contained macula utriculi, macula sacculi and cristae ampullares from the semicircular canals. The incubation buffer was HBSS $(137.9 \mathrm{mM}$ $\mathrm{NaCl}, 5 \mathrm{mM} \mathrm{KCl}, 1.3 \mathrm{mM} \mathrm{CaCl}, 0.3 \mathrm{mM} \mathrm{KH}_{2} \mathrm{PO}_{4}, 5$

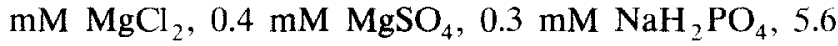
$\mathrm{mM}$ D-glucose) with $5 \mathrm{mM}$ sodium $\mathrm{N}$-2-Hydroxyethylpiperazine- $N$ '-2-ethanesulfonic acid (HEPES). It was gassed with $95 \% \mathrm{O}_{2} / 5 \% \mathrm{CO}_{2}$ for $30 \mathrm{~min}$, its $\mathrm{pH}$ titrated to $7.4 \pm 0.01$ with $\mathrm{NaOH}$ and then its osmolality adjusted to $300 \pm 2 \mathrm{mOsm}$ with $\mathrm{NaCl}$.

\subsection{Labeling of inositol phospholipids and release of inositol phosphates}

Methods for radioactive labeling of phosphoinositides and the separation of inositol phosphates (InsPs) were essentially as previously reported (Niedzielski and Schacht, 1991; Ogawa and Schacht, 1993a). Tissues were placed in $50 \mu \mathrm{l}$ of incubation buffer with $1 \mathrm{mM}$ cytidine and $16 \mu \mathrm{Ci} m y o-\left[{ }^{3} \mathrm{H}\right]$ inositol for $2 \mathrm{~h}$ at $37^{\circ} \mathrm{C}$. myo- $\left[{ }^{3} \mathrm{H}\right]$ Inositol was removed by two washes $(0.5 \mathrm{ml}$ each) with buffer free of radioactivity. Incubation continued for $10 \mathrm{~min}$ in $90 \mu \mathrm{l}$ of buffer with $10 \mathrm{mM} \mathrm{LiCl}$. Finally, agonists were added in $10 \mu \mathrm{l}$ of buffer to yield concentrations of $1 \mathrm{mM}$ carbamylcholine $(\mathrm{CCh})$ or 200 $\mu \mathrm{M}$ adenosine $5^{\prime}-O$-(3-thiotriphosphate) (ATP- $\gamma$-S) and the incubation was continued for $30 \mathrm{~min}$. The duration of the incubation assured optimal labeling and viability of the tissues (Niedzielski and Schacht, 1991; Niedzielski et al., 1992). Phosphoinositide hydrolysis was terminated with $300 \mu \mathrm{l}$ of chloroform/methanol $(1: 2$ by vol). One hundred $\mu \mathrm{l}$ of phytic acid hydrolysate (prepared by heating $4 \mathrm{mg}$ phytic acid in $1 \mathrm{ml}$ of $30 \mathrm{mM}$ acetic acid $/ 65 \mathrm{mM}$ sodium acetate for $48 \mathrm{~h}$ at $95^{\circ} \mathrm{C}$, quenching with $20 \mu \mathrm{l}$ of $1 \mathrm{~N} \mathrm{NaOH}$ and diluting $1: 100$ with $\mathrm{H}_{2} \mathrm{O}$ ) and $200 \mu$ l of bovine brain extract in 
chloroform $(0.2 \mathrm{mg}$ of Sigma type IV $/ \mathrm{ml})$ were added as carriers to reduce loss of labeled InsPs and lipids during their isolation. The aqueous and chloroform phases were separated by centrifugation. One hundred $\mu l$ of the chloroform phase were dried down before radioactivity in phosphoinositide lipids was determined by liquid scintillation counting.

InsPs in the aqueous phase were separated from myo-inositol after Berridge et al. (1983) and Dean and Beaven (1989) with minor modifications. Two hundred $\mu l$ of sample were diluted to $1.5 \mathrm{ml}$ with distilled water and passed over Dowex-1 formate (cross-linkage $8 \%$, mesh size 200-400; column, $25 \times 5 \mathrm{~mm}$ ). The column was first washed with $8 \mathrm{ml}$ of $5 \mathrm{mM}$ myo-inositol. Individual inositol phosphates were separated by sequential elution with $5 \mathrm{ml}$ of $5 \mathrm{mM}$ sodium tetraborate in $60 \mathrm{mM}$ sodium formate (glycerophosphoinositol, GPI), $0.2 \mathrm{M}$ ammonium formate in $0.1 \mathrm{mM}$ formic acid (inositol monophosphate, InsP), $0.4 \mathrm{M}$ ammonium formate in $0.1 \mathrm{mM}$ formic acid (inositol bisphosphate, InsP $\mathrm{P}_{2}$ ), $1 \mathrm{M}$ ammonium formate in $0.1 \mathrm{mM}$ formic acid (inositol trisphosphate, $\operatorname{Ins}_{3}$ ). When total combined InsPs were measured, the sequential steps were replaced by a single elution with $5 \mathrm{ml}$ of $1 \mathrm{M}$ ammonium formate in $0.1 \mathrm{M}$ formic acid. Radioactivity of each fraction was determined by liquid scintillation counting. Columns were used for 5 experiments by regenerating with $10 \mathrm{ml}$ of $1 \mathrm{M}$ sodium formate in $0.1 \mathrm{M}$ formic acid and $10 \mathrm{ml}$ of distilled water.

\subsection{Hydrolysis of inositol phospholipids}

The hydrolysis of phosphoinositides was measured in a 'chase' experiment. Tissues were labeled for $2 \mathrm{~h}$ with myo- $\left[{ }^{3} \mathrm{H}\right]$ inositol as described above, washed and further incubated with $1 \mathrm{mM}$ non-radioactive myo-inositol at $37^{\circ} \mathrm{C}$. After termination of the reaction, the chloroform phase was washed with $500 \mu \mathrm{l}$ of $2.4 \mathrm{~N} \mathrm{HCl}$ and an aliquot counted for radioactivity. The remainder of the chloroform phase was dried under $\mathrm{N}_{2}$ and stored at $-20^{\circ} \mathrm{C}$ until the thin layer chromatographic separation. HPTLC plates were pretreated overnight in methanol $/ \mathrm{H}_{2} \mathrm{O}(2: 3$, by vol.) containing $0.01 \mathrm{~g}$ of potassium oxalate per ml of solvent. Plates were activated by heating at $100^{\circ} \mathrm{C}$ for $45 \mathrm{~min}$ just prior to use. Dried lipids were dissolved in $30 \mu \mathrm{l}$ of chloroform/ methanol $(1: 2$, by vol.) and spotted along with standards of phosphoinositides. The plates were developed for $45 \mathrm{~min}$ at $4^{\circ} \mathrm{C}$ with chloroform/acetic acid/ methanol/acetone $/ \mathrm{H}_{2} \mathrm{O} \quad(40: 15: 13: 12: 7$, by vol. $)$. After drying the plates, phospholipids were visualized by molybdenum blue $(0.65 \%$ molybdenum oxide in 4.2 $M$ sulfuric acid). Bands corresponding to phosphatidylinositol (PtdIns), phosphatidylinositol 4-monophosphate (PtdInsP) and PtdInsP, were scraped oft and radioactivity was determined by scintillation counting.

\subsection{Measurement of myo-inositol}

CSE and VSE were homogenized by sonication in $150 \mu \mathrm{l}$ of HBSS with $5 \mathrm{mM}$ HEPES, pH 7.4, and centrifuged at $3000 \times g$ for $5 \mathrm{~min}$. myo-Inositol in the supernatant was assayed by high performance liquid chromatography (HPLC), modified from Kargacin et al. (1987). myo-Inositol was derivatized by incubating $30 \mu \mathrm{l}$ of sample with $30 \mu \mathrm{l}$ each of $10 \mathrm{mM}$ aqueous triethylamine and $10 \mathrm{mM}$ isatoic anhydride in dimethylsulfoxide for $15 \mathrm{~min}$ at $60^{\circ} \mathrm{C}$. Eighty $\mu$ l of the mixture were injected onto a nucleotide/nucleoside reversed phase column $(250 \times 4.6 \mathrm{~mm}$; Alltech Assoc., Deerfield, IL) protected by a guard column with pellicular C18 packing. A linear gradient from $10 \%$ methanol/ $90 \%$ aqueous acetic acid. pH 3.4 , to $100 \%$ methanol was applied in $30 \mathrm{~min}$, followed by a 10 -min hold at $100 \%$ methanol and a 10 -min reverse gradient to the starting conditions. Because of its multiple functional groups, the derivatization resulted in several peaks for myo-inositol which were detected with a FDI00 filter fluorimeter (GTI/SpectroVision, Concord, MA) using a $330 \mathrm{~nm}$ excitation filter and a $400 \mathrm{~nm}$ cut-off emission filter. The earliest eluting myo-inositol peak was

Table 1

Agonist-stimulated myo- $\left[{ }^{3} \mathrm{H}\right]$ inositol phosphate release

\begin{tabular}{|c|c|c|c|c|}
\hline \multirow[t]{2}{*}{ Agonist } & \multicolumn{2}{|l|}{$\mathrm{CSE}$} & \multicolumn{2}{|l|}{ VSE } \\
\hline & Young & Old & Young & Old \\
\hline \multicolumn{5}{|l|}{ (dpm [ $\left.{ }^{3} \mathrm{H}\right] \mathrm{Ins}$ Ps $/ \mu \mathrm{g}$ protein $)$} \\
\hline Control & $4184 \pm 590$ & $6826 \pm 1596^{*}$ & $4690 \pm 810$ & $6480+1818 *$ \\
\hline $\mathrm{CCh}$ & $8214 \pm 1928$ & $14133 \pm 2661 * *$ & $10021 \pm 2386$ & $11752 \pm 2619$ \\
\hline $\begin{array}{l}\text { ATP- } \gamma-\mathrm{S} \\
\text { (\% of control without agonist) }\end{array}$ & $22089+3793$ & $42270 \pm 14787 *$ & $24437 \pm 7046$ & $46847 \pm 7181 * *$ \\
\hline $\mathrm{CCh}$ & $196 \pm 37$ & $222 \pm$ & $222 \pm 75$ & $195 \pm 72$ \\
\hline$A T P-Y-S$ & $540 \pm 141$ & $662 \pm$ & $594 \pm 126$ & $759 \pm 172$ \\
\hline
\end{tabular}

$\mathrm{CSE}$ and VSE were prelabelled with $16 \mu \mathrm{Ci}$ myo- $\left[{ }^{3} \mathrm{H}\right]$ inositol for $2 \mathrm{~h}$ and then incubated with $1 \mathrm{mM} \mathrm{CCh}$ or $200 \mu \mathrm{M}$ ATP- $\gamma-\mathrm{S}$ for $30 \mathrm{~min}$. Data are means \pm SD of 6 independent experiments. Stimulation in aged tissue differs from that in corresponding young tissuc: $* 0.01<1<0.05$; ** $P<0,01$ (paired Student's $t$-test). 
used for quantification by peak height, calibrated against a myo-inositol standard.

\subsection{Other procedures}

Protein was determined after Bradford (1976) using bovine scrum albumin as a standard. Results are reported as means \pm SD. Statistical significance of differences between young and aged tissues was tested using two-tailed paired Student's $t$-test.

The care and use of animals reported in this study were reviewed under grants DC-00078 and AG-08885, and approved by the University of Michigan Unit on Laboratory Animal Medicine.

\section{Results}

\subsection{Receptor-mediated release of myo-inositol phos- phates}

In the CSE, basal unstimulated release of $\left[{ }^{3} \mathrm{H}\right] \mathrm{InsPs}$ was $4184 \pm 590 \mathrm{dpm} / \mu \mathrm{g}$ protein in young ( 3 months old) and $6826 \pm 1596 \mathrm{dpm} / \mu \mathrm{g}$ protein in aged rats $(24$ months old). In the VSE, a similar increase with age was seen: total InsPs were $4690 \pm 810 \mathrm{dpm} / \mu$ g protein and $6489 \pm 1818 \mathrm{dpm} / \mu \mathrm{g}$ protein in young and aged rats, respectively (Table 1 ). A trend towards age-dependent increases was also evident in the radioactivity of individual InsPs in both the CSE and VSE (Fig. 1).

CCh stimulated the release of InsPs approximately 2 -fold, and ATP- $\gamma$-S 5- to 7-fold. Both agonists released more $\left[{ }^{3} \mathrm{H}\right] \mathrm{InsPs}$ (per $\mu \mathrm{g}$ protein) in both the aged CSE and VSE (Table 1). This trend was also seen in individual InsPs (Fig. 1).

\subsection{Phospholipid labeling and hydrolysis}

Incorporation of myo- $\left[{ }^{3} \mathrm{H}\right]$ inositol (expressed as radioactivity per $\mu \mathrm{g}$ protein) into phosphoinositide lipids, precursors of InsPs, was also increased significantly by age in both the CSE and VSE (Table 2). Radioactivity was primarily found in PtdIns; the polyphosphoinositides, PtdInsP and PtdInsP $P_{2}$, represented about $10 \%$ of the total $\left[{ }^{3} \mathrm{H}\right]$ inositol lipids. There were no age-related changes in the distribution of radioactivity among the phosphoinositides. This pattern was similar between the CSE and VSE and between young and old rats.

The rate of hydrolysis of phosphoinositides was determined by incubating prelabeled lipids with excess non-radioactive myo-inositol. Radioactivity in all three phosphoinositides decreased by $40 \%$ to $50 \%$ during the chase period. There was, however, no significant difference in the rate of hydrolysis with age in any of the lipids in either the CSE and VSE (Fig. 2).
Cuchlear sensur y epithelium Vestibular sensory epithelium
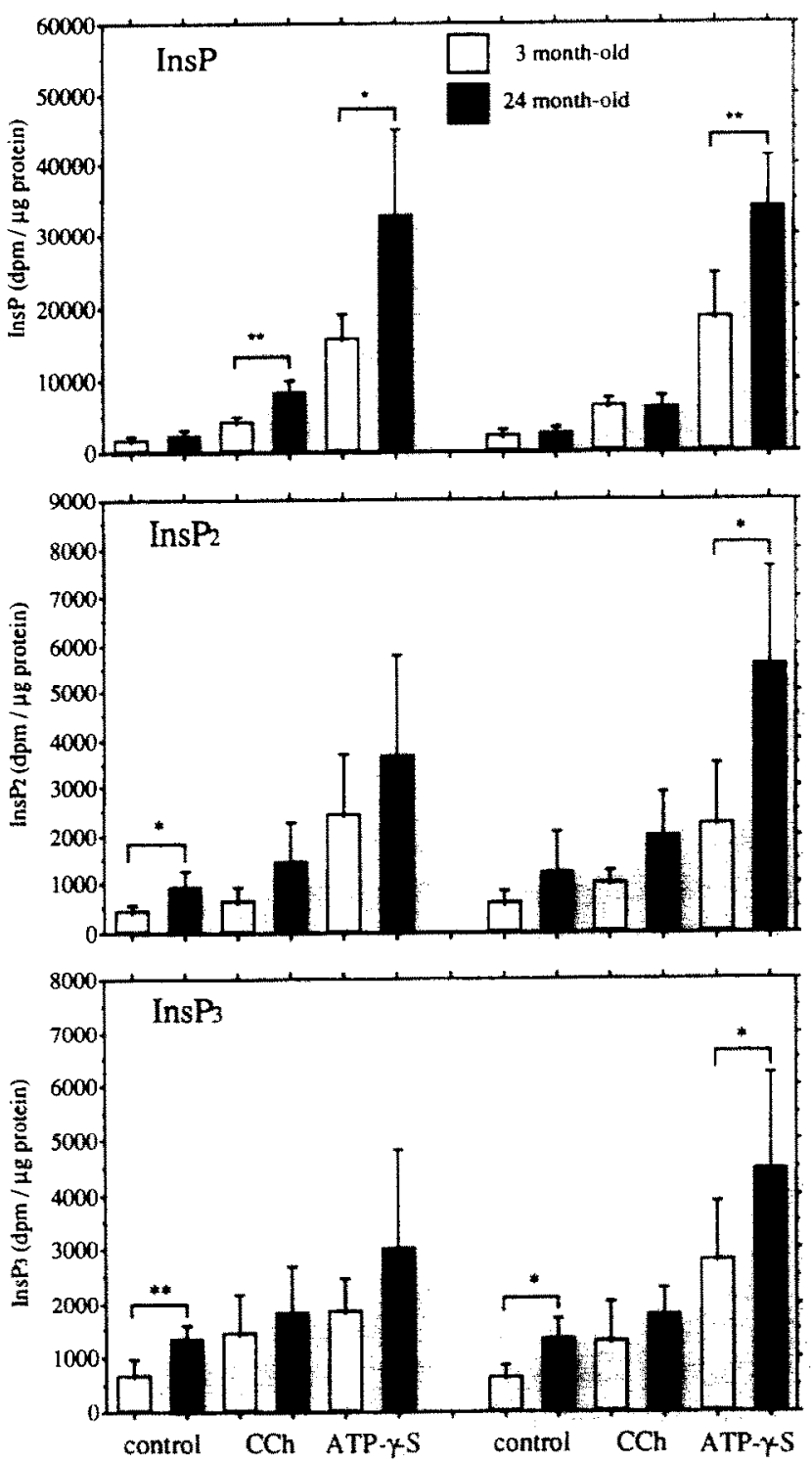

Fig. 1. Effects of aging on agonist-stimulated release of InsP, Ins: $P_{2}$ and Ins $\mathrm{P}_{3}$. CSE and VSE were prelabelled with $16 \mu \mathrm{Ci}$ myo $-\left[{ }^{3} \mathrm{H}\right] \mathrm{in}-$ ositol for $2 \mathrm{~h}$ and then incubated with $1 \mathrm{mM} \mathrm{CCh}$ or $200 \mu \mathrm{M}$ $\mathrm{ATP} \cdot \gamma-\mathrm{S}$ for $30 \mathrm{~min}$ as described in Materials and methods. The results are expressed as $\mathrm{dpm}$ of individual InsPs per $\mu \mathrm{g}$ protein. Each figure is the mean $\pm S D$ of 6 independent experiments. Statist $i$ cal significance of differences between young and aged tissues was determined by paired Student's $t$-test $\left(* 0.01<P<0.05 ;{ }^{*} P<\right.$ $0.01)$.

\subsection{Tissue concentration and uptake of myo-inositol}

The myo-inositol content was $314 \pm 96$ and $175 \pm 28$ $\mu \mathrm{mol} / \mu \mathrm{g}$ protein in young and aged CSE, respectively, representing a significant $44 \%$ decrease with agc. In the VSE, myo-inositol content was decreased by $24 \%$ in aged rats from $110 \pm 27$ to $84 \pm 8 \mu \mathrm{mol} / \mu \mathrm{g}$ protein. In contrast to the endogenous myo-inositol content, the added $m y o-\left[{ }^{3} \mathrm{H}\right]$ inositol reached significantly higher concentrations in the aged tissues (Table 3 ). 
Table 2

$m y o-\left[{ }^{3} \mathrm{H}\right]$ Inositol labeling of phospholipids

\begin{tabular}{|c|c|c|c|c|}
\hline \multirow[t]{2}{*}{ Lipid } & \multicolumn{2}{|l|}{$\mathrm{CSE}$} & \multicolumn{2}{|l|}{ VSE } \\
\hline & Young & Old & Young & Old \\
\hline \multicolumn{5}{|l|}{$\left(10^{-3} \mathrm{dpm} / \mu \mathrm{g}\right.$ protein $)$} \\
\hline $\begin{array}{l}\text { PtdInsPs } \\
\text { (\% of total lipid radioactivity) }\end{array}$ & $59.4 \pm 4.7$ & $95.3 \pm 19.1 *$ & $107.7 \pm 5.6$ & $134.0 \pm 18.5 *$ \\
\hline Ptdlns & $87.4 \pm 2.5$ & $89.1 \pm 1.4$ & $90.2 \pm 1.4$ & $91.1 \pm 1.11$ \\
\hline PtdInsP & $7.6 \pm 1.6$ & $6.6 \pm 0.9$ & $6.3 \pm 1.1$ & $5.7 \pm 0.8$ \\
\hline PtdlnsP2 & $3.3 \pm 0.6$ & $3.0 \pm 1.0$ & $2.3 \pm 0.3$ & 2.110 .3 \\
\hline
\end{tabular}

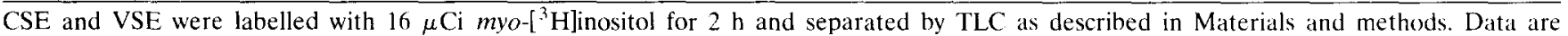
means \pm SD of 5 independent experiments. Incorporation in aged tissue differs from that in corresponding young tissue: * $* 0.01<P<0.05$ (paired Student's $t$-test).

\subsection{Protein content and normalization of data}

The protein content of the CSE and VSE remained unchanged with age $(10.6 \pm 3.1 \mu \mathrm{g}$ and $10.3 \pm 2.3 \mu \mathrm{g}$ in young and aged CSE; $13.4 \pm 4.6 \mu \mathrm{g}$ and $11.7 \pm 3.2 \mu \mathrm{g}$ in young and aged VSE) providing a basis for normalizing the radiolabeling and comparing results from different experiments as shown above. This normalization reflects the overall incorporation of the added myo$\left[{ }^{3} \mathrm{H}\right]$ inositol. It does not account for specific relationships between radioactive products and their precursors. This relationship becomes evident when radioactive labeling of PtdInsPs is compared to the myo- $\left[{ }^{3} \mathrm{H}\right]$ inositol pool, and labeling of InsPs to that of PtdInsPs. Similarly, the agonist-stimulated InsPs release can be expressed as percent of the corresponding unstimu-
Cochlear sensory epithelium
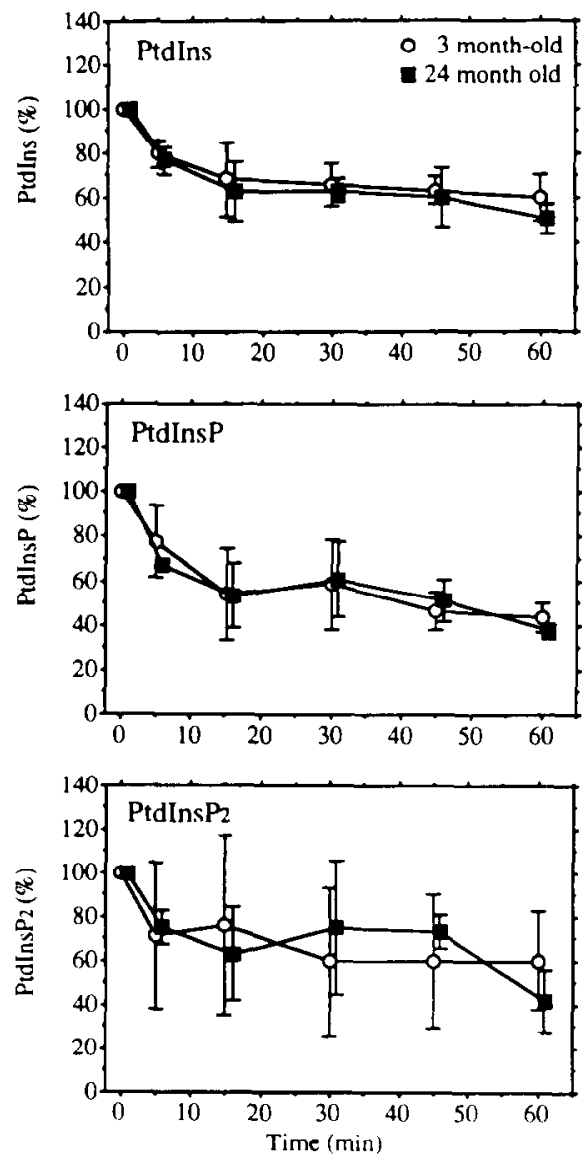

Vestibular sensory epithelium
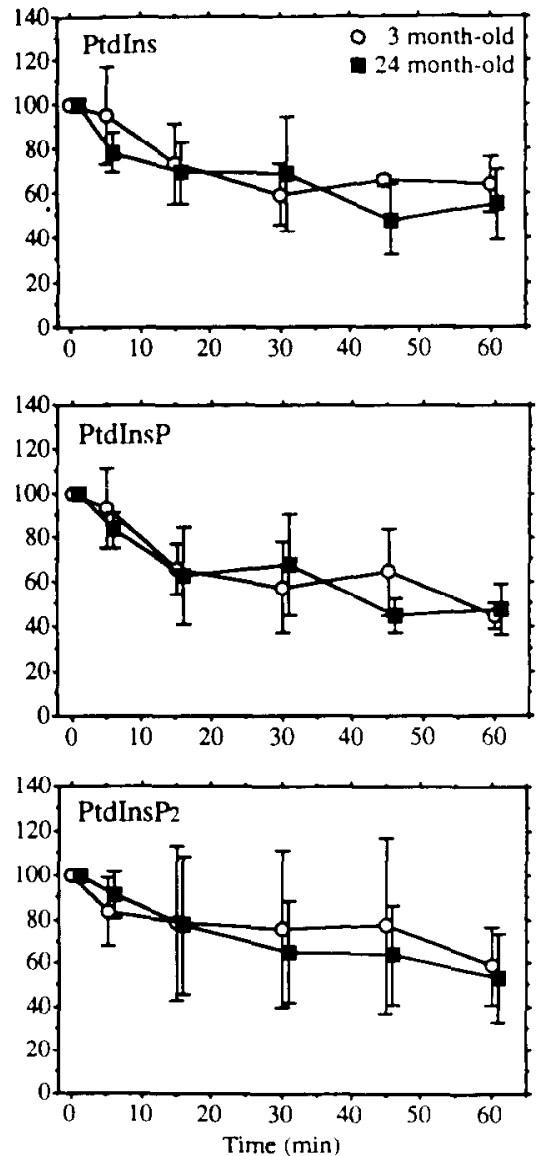

Fig. 2. Hydrolysis of phosphoinositides in young and aged CSE and VSE. Tissues were labeled with myo- $\left[{ }^{3} \mathrm{H}\right]$ inositol and subsequently incubated with $1 \mathrm{mM}$ non-radioactive myo-inositol as described in Materials and methods. Results are expressed as of radioactivity present at 0 min of the 'chase', i.e. after the prelabeling period. Each bar is the mean $\pm \mathrm{SD}$ of 5 independent experiments. 
Table 3

Tissue contents of endogenous myo-inositol and of myo- $\left[{ }^{3} \mathrm{H}\right]$ inosito

\begin{tabular}{lll} 
CSE & VSE \\
\cline { 2 - 4 } & Young Old & \\
\hline
\end{tabular}

myo-Inositol

$(\mu \mathrm{mol} / \mu \mathrm{g}$ protein) $314 \pm 96175 \pm 28 * 110 \pm 27 \quad 84 \pm 8 *$ myo- $\left[{ }^{3} \mathrm{H}\right]$ inositol

$\left(10^{-3} \mathrm{dpm} /\right.$

$\mu \mathrm{g}$ protein)

$165 \pm 40213 \pm 43 * 160+44229 \pm 50 * *$

myo-Inositol content was measured in individual samples from 4 animals in each category as described in Materials and methods. myo-[ $\left.{ }^{3} \mathrm{H}\right]$ inositol uptake was determined from 18 experiments as the total radioactivity (InsPs, PtdInsPs and free $m y o$-inositol) after incubation with $16 \mu \mathrm{Ci}$ myom $\left[{ }^{3} \mathrm{H}\right]$ inositol for $2 \mathrm{~h}$ as described in Materials and methods. Data are means $\pm S D$. Kesults in aged tissue differ from those in corresponding young tissue: $* 0.01<P<0.05 ; * * P<$ 0.01 (paired Student's $t$-test).

lated control. With these methods of normalization, there was no significant difference with age in lipid labeling (i.e., the pathway from myo-inositol to PtdInsPs), in InsPs release (i.e., the pathway from PtdInsPs to InsPs) or in agonist-induced $\left[{ }^{3} \mathrm{H}\right] \mathrm{InsP}$ s release. The last example is shown in Table 1.

\section{Discussion}

Incorporation of myo- $\left[{ }^{3} \mathrm{H}\right]$ inositol into phosphoinositides and InsPs was significantly enhanced in both the CSE and VSE of 24-month- old rats. Concomitantly, the carbamylcholine- and ATP-stimulated release of $\left[{ }^{3} \mathrm{H}\right] \mathrm{InsPs}$ increased. Since the amount of protein recovered from young and old inner ears remained unchanged, this increase of myo- $\left[{ }^{3} \mathrm{H}\right]$ inositol incorporation is not caused by loss of tissue or by age-related decreases in protein content of these organs.

An accelerated turnover of phosphoinositides or enhanced responsiveness to hormonal stimulation could lead to the observed effects. Alternately, changes in the specific radioactivity of the precursor pool of myo$\left[{ }^{3} \mathrm{H}\right]$ inositol could be reflected in the radiolabeling of lipids and InsPs. The sum of the experimental evidence suggests that the latter mechanism may account for the results. While the amount of radioactivity is higher in the lipids and InsPs of aged tissues, the rate of their formation and their turnover does not seem to be affected. This becomes evident when radioactivity in the products (lipids and InsPs) is compared to radioactivity in the corresponding precursors (myo-inositol and PtdInsPs). On this basis, there is no difference between young and aged animals. Supporting this notion is the fact that hydrolysis of PtdInsPs remains unchanged, as measured directly in the 'chase' experiment. Furthermore, agonist-stimulated InsPs release is of the same magnitude (percent stimulation) in aged
CSE and VSE. Thus, there appear to he no changes with aging in phosphoinositide turnover and coupling of cholinergic and purinergic receptors to phospholipase $\mathrm{C}$ and the formation of InsPs. This finding is also compatible with the absence of differences in the levels of the efferent neurotransmitter acetylcholine between 3-, 12- and 24-month-old rats (Hoffman et al., 1988). The lack of an effect in the inner ear and the fact that both age-dependent increases and decreases of receptor-mediated InsPs release have been observed in other tissues (see references in the introduction) indicate a high degree of complexity of aging effects on the Ins $\mathrm{P}_{3}$ second messenger system.

In the synthesis of phosphoinositides, free intracellular myo-inositol is incorporated into PtdIns via a reaction with CDP-diglyceride. PtdIns midy then be phosphorylated stepwise to PtdInsP and PtdIns $P_{2}$. Ins $P_{3}$, derived by the hydrolysis of PtdIns $P_{2}$, is eventually dephosphorylated to yield free myo-inositol (Majerus, 1992). Two mechanisms maintain cellular myo-inositol levels: (1) de novo synthesis from glucose 6-phosphate catalyzed by myo-inositol 1-phosphate synthase; and (2) uptake of circulating myo-inositol via a non-saturable, energy-independent process, or a saturable, $\mathrm{Na}^{+}$-dependent process (Sherman, 1989, for review). The relative contributions of these pathways in the inner ear are not known.

The significant decrease in the myo-inositol concentration suggests an age-dependent inability to maintain the endogenous myo-inositol pool. Although the mechanisms underlying this decrease remain to be established, the fact that myo-inositol content in aged human brain is half the level in young brain (Stokes et al., 1983) corresponds with our observations. Furthermore, tissue levels of the added $m y o-\left[{ }^{3} \mathrm{H}\right]$ inositol were higher in aged CSE and VSE. While this may suggest changes in an active transport mechanism, it may also reflect an altered equilibrium due to lower endogenous myo-inositol. In any case, a decreased myo-inositol content coupled with increased uptake of myo- $\left[{ }^{3} \mathrm{H}\right]$ inositol would result in a precursor pool of higher specific radioactivity and consequently, in higher radioactivity in lipids and InsPs.

Depletion of cellular myo-inositol may in itself induce pathological changes. The participation of myoinositol in osmoregulation and volume control is particularly interesting in the context of inner ear dysfunction. The role of outer hair cells as modulators of the transduction process may be intimately linked to proper maintenance of their intracellular pressure. The cytoplasm of outer hair cells is hyperosmotic but the responsible osmotic agent is unknown (Brownell, 1990). Turgor in these cells in part sustains their shape and their coupling to micromechanical events on the basilar membrane. Loss in turgor is associated with diminished electromotility (Brownell and Shehata, 1990) which in 
turn may compromise tuning and sensitivity in the auditory periphery. Slow shape changes in response to elevation of intracellular calcium may also depend on intracellular pressure (Dulon et al., 1990). The role of turgor in cells of the VSE is not known but we can speculate that proper function of the vestibular apparatus also requires intact mechanisms of pressure homeostasis. If myo-inositol participates as an organic osmolyte in the maintenance of hair cell turgor, then its depletion should result in the subtle pathophysiological changes that are observed in aging animals.

In summary, myo-inositol metabolism is crucial for cell physiology as a constituent of volume-regulating and second messenger systems. The decreased myo-inositol content in aged rats suggests impaired myo-inositol synthesis or uptake, possibly compromising osmoregulation in the sensory epithelia. It remains open whether the limited availability of myo-inositol additionally leads to compensatory mechanisms of lipid metabolism and transmembrane signaling. Such changes would presently be masked by the differences in the myo-inositol precursor pool. Further study will be needed to establish the effects of aging on the molecular mechanisms regulating hair cell turgor, calcium homeostasis and motility in CSE and VSE.

\section{Acknowledgements}

The authors wish to thank Sherry Ann Crann for her thoughtful suggestions for this study. This work was supported by research grant AG-08885 from the National Institute of Health.

\section{References}

Barritt, G.J. (1987) Intracellular free calcium and inositol polyphosphate action as potential targets in the aging process. Neurobiol. Aging 8, 359-361.

Bastyr III, E.J., Kadrofske, M.M. and Vinik, A.I. (1990) Platelet activity and phosphoinositide turnover increase with advancing age Am. J. Med. 88, 601-606.

Berridge, M.J. (1993) Inositol triphosphate and calcium signalling. Nature 361. 315-325.

Berridge, M.J.. Dawson, R.M.C., Downes, C.P., Heslop, J.P. and Irvine, R.F. (1983) Changes in the levels of inositol phosphates after agonist-dependent hydrolysis of membrane phosphoinositides. Biochem. J. 212, 473-482.

Bonetti, A.C., Bellini, F., Carderini, G., Galbiati, E. and Toffano, G. (1987) Age-dependent changes in the mechanisms controlling prolactin secretion and phosphatidylinositol turnover in male rats: effect of phosphatidylserine. Neuroendocrinology 45, 123129.

Borst, S.E. and Scarpace, P.J. (1990) Alpha1-adrenergic stimulation of inositide hydrolysis in liver of senescent rats. Mechan. Ageing Dev. 56, 275-280.
Bradford, M.M. (1976) A rapid and sensitive method for the quantitation of microgram quantities of protein utilizing the principle of protein-dye binding. Anal. Biochem. 72, 248-254.

Brownell, W.E. (1990) Outer hair cell electromotility and otoacoustic emissions. Ear Hear. 11, 82-92.

Browncll. W.E. and Shchata, W.E. (1990) The effect of cytoplasmic turgor pressure on the static and dynamic mechanical properties of outer hair cells. In: P. Dallos, C.G. Geisler, J.W. Matthews. M.A. Ruggero and C.R. Steele (Eds.), Mechanics and Biophysics of Hearing. Springer, New York, pp. 52-60).

Burnett. D.M.. Daniell, I.C. and 7ahniser. N.R. (199()a) Decreased efficacy of inositol 1,4,5-triphosphate to elicit calcium mobilization from cerebrocortical microsomes of aged rats. Mol. Pharmacol. 37, 566-571.

Burnett. D.M., Bower, J.F.. Masserano. J.M. and Zahniser, N.R (1990b) Effect of aging on alfa-1 adrenergic stimulation of phosphoinositide hydrolysis in various regions of rat brain. I. Pharmacol. Exp. Ther. 255, 1265-1270).

Cooper. W.A. Jr, Coleman, J.R. and Newton, E.H. (1990) Auditory brainstem responses to tonal stimuli in young and aging rats. Hear. Res. 43, 171-180.

Crews, F.T., Gonzales, R.A., Palvocik, R.. Phillips, M.l.. Theiss, C. and Raizada, M. (1986) Changes in receptor stimulated phosphoinositides hydrolysis in brain during ethanol administration. aging, and other pathological conditions. Psychopharmacol. Bull. $22,775-780$.

Dean, N.M. and Beaven, M.A. (1989) Methods for the analysis of inositol phosphate. Anal. Biochem. 183, 199-209.

Dulon, D. Zajic, G. and Schacht. J. (1990) Increasing intracellular free calcium induces circumferential contractions in isolated cochlear outer hair cells. J. Neurosci. 10,1388-1,397.

Fulop. Jr., T.. Varga. Z., Csongor, J., Foris, G. and Leovey, A. (1989) Age related impairment in phosphatidylinositol breakdown of polymorphonuclear granulocytes. FEBS Lett. 245, 249-252.

Garcia-Perez, A. and Burg, M.B. (199(1) Importance of organic osmolytes for osmoregulation by renal medullary cells. Hypertension 16, 595-602.

Gibson, G.E. and Peterson, C. (1987) Calcium and the aging nervous system. Neurobiol. Aging 8, 329-343.

Guiramand, J., Mayat, E., Bartolami, S., Lenoir, M.. Rumigny, J.-F., Pujol, R. and Récasens, M. (1990) A M3 muscarinic receptor coupled to inositol phosphate formation in the rat cochlea? Biochem. Pharmacol. 39, 1913-1919

Henzi, V. and MacDermott, B. (1992) Characteristics and function of $\mathrm{Ca}^{2+}$ - and inositol 1,4,5-triphosphate-releasable stores of $\mathrm{Ca}^{2+}$ in neurons. Neuroscience 46, 251-273.

Hoffman, D.W., Jones-King, K.L. and Altschuler. R.A. (1988) Putative neurotransmitters in the rat cochlea at several ages. Brain Res. 460. 366-368.

Irvine, R.F. (1992) Inositol phosphates and $\mathrm{Ca}^{2}+$ entry: toward a proliferation or a simplification? FASEB J. 6, 3085-30101.

Ishikawa, Y., Gee, M.V., Ambudkar, I.S., Bodner. L.. Baum, B.J. and Roth. G.S. (1988) Age-related impairment in rat parotid cell al-adrenergic action at the level of inositol triphos-phate responsiveness. Biochim. Biophys. Acta 968. 203-210.

Joseph. J.A., Kowatch, M.A., Maki, T. and Roth, G.S. ( I990) Selective cross-activation/inhibition of second messenger systems and the reduction of age-related deficits in the muscarinic control of dopamine release from perifused rat striata. Brain Res. 537, $40-48$.

Kargacin, M.E., Bassell, G., Ryan, P.J. and Honeyman, T.W. (1987) Separation and analysis of fluorescent derivatives of myo-inositol and myo-inositol 2-phosphate by high-performance liquid chromatography. J. Chromatogr. 393, 454-458.

Kurian. P.. Narang, N. and Crews. F.T. (1992) Decreased carbacholstimulated inositol 1,3,4,5-tetrakisphosphate formation in senescent rat cerebral cortical slices. Neurobiol. Aging 13, 521-526. 
Laitinen, J.T., Vakkuri, O. and Saavedra, J.M. (1992) Pineal muscarinic phosphoinositide responses; age-associated sensitization, agonist-induced desensitization and increase in melatonin release from cultured pineal glands. Neuroendocrinology 55, 492-499.

Majerus, P.W. (1992) Inositol phosphate biochemistry. Annu. Rev. Biochem. 61, 225-250.

Miyamoto, A. and Ohshika, H. (1989) Age-releted changes in $\left[{ }^{3} \mathrm{H}\right]$ prazosin binding and phosphoinositide hydrolysis in rat ventricular myocardium. Gen. Pharmacol. 20, 647-651.

Moscona-Amir, E., Henis, Y.I. and Sokolovsky, M. (1989) Aging of rat heart myocytes disrupts muscarinic receptor coupling that leads to inhibition of CAMP accumulation and alters the pathway of muscarinic-stimulated phosphoinositide hydrolysis. Biochemistry $28,7130-7137$.

Mundy, W., Tandon, P., Ali, S. and Tilson, H. (1991) Age-related changes in receptor-mediated phosphoinositide hydrolysis in various regions of rat brain. Life Sci. 49, 97-102.

Nalepa, I., Pintor, A., Fortuna, S., Vetulani, J. and Michalek, H (1989) Increased responsiveness of the cerebral cortical phosphatidylinositol system to noradrenaline and carbachol in senescent rats. Neurosci. Lett. 107, 195-199.

Niedzielski, A.S. and Schacht, J. (1991) Phospholipid metabolism in the cochlea: Differences between base and apex. Hear. Res. 57 $107-112$.

Niedzielski, A.S. and Schacht, J. (1992) P2 purinoceptors stimulate inositol phosphate release in the organ of Corti. NeuroReport 3 , 273-275.

Niedzielski, A.S., Ono, T. and Schacht, J. (1992) Cholinergic regulation of the phosphoinositide second messenger system in the guinea pig organ of Corti. Hear. Res. 59, 250-254.

Ogawa, K. and Schacht, J. (1993a) Receptor-mediated release of inositol phosphates in the cochlear and vestibular sensory epithelia of the rat. Hear. Res. 69, 207-214.

Ogawa, K. and Schacht, J. (1993b) Effects of aging on receptor-mediated release of inositol phosphates in the organ of Corti and vestibule of the rat. Abst. Assoc. Res. Otolaryngol. 16, 91.

Ohnuki, T. and Nomura, Y. (1991) M1 acetylcholine receptor-media- ted phosphatidylinositol turnover in adult and senescent rat brain slices. Jap. J. Pharmacol. 57, 483--493.

Oosterveld, W.F. (1983) Changes in vestibular function with increasing age. In: R. Hinchchilffe (Ed.), Hearing and Balance in the Elderly, Churchill Livingstone, New York, pp. 354-372.

Paredes, A., McManus, M., Kwon, H.M. and Strange, K. (1942) Osmoregulation of $\mathrm{Na}(+)$-inositol cotransporter activity and mRNA levels in brain glial cells. Am. J. Physiol. 263, C1282C1288

Schuknecht, H.F. (1974) Presbycusis. In: H.F. Schuknecht (Ed.), Pathology of the Ear, Harvard University Press, Cambridge, MA. pp. 388-409

Sherman, W.R. (1989) Inositol homeostasis, lithium and diabetes. In: R.H. Michell, A.H. Drummond and C.P. Downes (Eds.), Inositol Lipids in Cell Signalling, Academic Press, San Diego, CA, pp. 39-79.

Simpson, G.V.. Knight, R.T., Brailowsky, S., Prospero-Garcia, O. and Scabini, D. (1985) Altered peripheral and brainstem auditory function in aged rats. Brain Res. 348, 28-35.

Stokes, C.E., Gillon, K.R. and Hawthorne, J.N. (1983) Free and total lipid myo-inositol concentrations decrease with age in human brain. Biochim. Biophys. Acta 753, 136-138.

Tandon, P., Mundy, W.R., Ali, S.F., Nanry, K., Rogers, B.C. and Tilson, H.A. (1991) Pharmacol. Biochem. Behav, 38, 861-867.

Undie, A.S. and Friedman, E. (1992) Aging-induced decrease in dopaminergic-stimulated phosphoinositide metabolism in rat brain. Neurobiol. Aging 13, 505-511.

Wells, W.W. (1989) Inositol deficiency states as a guide to inositol function. In: R.H. Michell, A.H. Drummond and C.P. Downes (Eds.), Inositol Lipids in Cell Signalling, Academic Press, San Diego, CA, pp. 207-235.

Willis-Karp, M. (1991) Effects of age on muscarinic agonist-induced contraction and IP accumulation in airway smooth muscle. Life Sci. $49,1039-1045$.

Willott, J.F. (1991) Aging and the inner ear of animals. In: J.F. Willott (Ed.), Aging and the Auditory System, Singular Publishing Group, San Diego, CA, pp. 56-80. 